DOI 10.18551/rjoas.2021-09.08

\title{
ASSESSMENT OF THE EFFECT OF POVERTY AMONG RURAL WOMEN IN KAGARKO LOCAL GOVERNMENT AREA OF KADUNA STATE, NIGERIA
}

\author{
Alabi O.F.* \\ Department of Agricultural Extension and Management, \\ Federal College of Forestry Mechanization, Kaduna State, Nigeria \\ Ariyo O.C. \\ Department and Entrepreneurship and Innovative Agriculture, \\ Federal College of Forestry Mechanization, Kaduna State, Nigeria \\ Bala U.J., Omodona S. \\ Department of Crop Production, Federal College of Forestry Mechanization, \\ Kaduna State, Nigeria \\ Olafemi S.O. \\ Department of Agricultural Technology, Federal College of Forestry Mechanization, \\ Kaduna State, Nigeria \\ *E-mail: buk2lab@gmail.com
}

\begin{abstract}
This study examines assessment of poverty among rural women in Kagarko Local Government Area and the data was collected through well structured questionnaire from 114 respondents who were selected through a multistage sampling technique. Analytical technique used was descriptive statistics and Foster Greer Thorbecke (FGT) indices. The major poverty coping strategies used by the respondents were $78.95 \%$ collect gifts from their family members, $85.96 \%$ sell their farm produce, $87.72 \%$ pray to God in the church or mosque, $76.32 \%$ involve themselves in town development unions. $86.84 \%$ use their personal savings to cope with poverty, $71.93 \%$ of the respondents borrow from friends and relations. All the respondents were adversely affected by poverty in the study area such as $79.82 \%$ of the women had low standard of poor crude storage processing equipment, $83.3 \%$ had lack of access to funds, $64.91 \%$ had low accessibility to market, $69.30 \%$ had poor housing conditions.
\end{abstract}

\section{KEY WORDS}

Poverty, rural women, income, Foster Greer Thorbecke indices.

The case of poverty in Nigeria has reached an alarming rate because of the most pathetic feature of Nigeria society today is that, poverty of its members are living in a State of destitution while the remaining relatively insignificant minority are in affluence. Poverty is multifaceted and has no single universally accepted definition. Poverty is a social and economic phenomenon described by a wide range of concepts. A theoretical concept is always used as a starting point for its measurement (Mares, 2004). There exists a wide range of poverty typologies. Poverty is conceived of as a multi-dimensional concept covering economic, environmental resources, socio-political, and health care aspects of deprivation. These various aspects of deprivations and their components are interconnected and negatively reinforce each other. The effects create a vicious cycle of poverty. This was underscored in the World Bank (2009) statement showing that poverty is characterized by cumulative deprivations such that one dimension of poverty is often the cause of or contributor to another dimension.

The history of women has been one that is associated with abject poverty. In Nigerian as in other parts of the world, the culture has been the grim responsibility of women. 
Ogwumike (2012), reported that two third of the work in the world were done by women. Yet women own only ten percent $(10 \%)$ of the world income. Women constitutes majority of the poor and are often the poorest, of the poor, the disadvantage and inequality they face because they are women shape their experience of poverty differently from that of men increase their vulnerability and makes it more challenging to climb out of poverty.

The bulk of agricultural production in Nigeria takes place in the rural areas and ironically, the level and incident of poverty is very pronounced in these areas (NPC, 2004). Another interesting aspect of poverty is that rural women are reportedly more vulnerable accounting for $70 \%$ of the poor Moghadam (2005) even when it is not gender exclusive. This may be attributed to gender inequalities. And women's inadequate accesses to pecuniary profitable asset that can enable them provide their basic needs. The situation however, has attracted poverty reduction, intervention/activities and programmes of various national and international organization and governments. These include that of the United State Agency International Development (USAID), that UN system also established a collaborative team that comprised of United Nation International Children Emergency Fund (UNICEF) International Labour Organization (ILO), World Health Organization (WHO), Food and Agricultural Organization (FAO) and the World Bank as the lead agency in order to achieved it mandate of poverty reduction in Nigeria. However women in the rural areas are unemployed, underemployed and lack the basic needs of life. Consequently, this study is an assessment of the effect of poverty among rural women in Kagarko Local Government Area in Kaduna state.

There is need to investigate the effect of poverty on rural women in Kagarko Local Government Area in Kaduna state. Another interesting aspect of poverty is that, rural women are more vulnerable accounting for $70 \%$ of the poor Moghadam (2005) even when it is not gender exclusive.

Henceforth, this study was used as a guide to students, researchers, institution on the poverty level of rural women in the study area. World Bank (2007) data also shows that the percentage of the population living in households with consumption or income per person below the poverty line has increased, also in areas like Kaduna state where there is a large proportion of women. The population is increasing and poverty still exist and is on the rise, bridging these gaps call for effort by the Government to go to the root by knowing the effect of poverty on households, their perception on it and their poverty coping strategies. In addition, study of this nature is necessary because it has a great potential to play a crucial role in contributing to poverty alleviation, further literature and adding to existing knowledge and better ways on which women especially can deal with poverty.

\section{METHODS OF RESEARCH}

The Study was conducted in Kagarko local government area of Kaduna State. Kagarko local government area located in the plain of the southern part of Kaduna State, it was cured out of the present Kachia Local government in 1996. This area shares common border with Niger and Nassarawa state, then the Federal Capital territory administration (FCT). The Local Government Area is hereterogeneous with geo-political setting having Koro, Hausa/Fulani and Gbagi as the three dominant tribes. Christianity and islam also form the major two religion been practiced by the people.

Primary data was used to gather information from the respondents with the use of well structured questionnaires. Information was obtained on the socio-economic characteristics of the respondents, such as their age, education, marital status etc, their poverty status, perception on poverty as well as effect to poverty in the study area.

The following under listed analytical tools was use to achieved the objectives of this studies. Descriptive statistics which was used to address the socioeconomic characteristics includes mean, percentages etc.

The method proposed by Foster, et al., (1984) has gained much popularity in the literature. This is used to calculate the poverty indices which consist of head count ratio, poverty gap and severity of poverty. The FGT index is given as: 


$$
F G T_{\alpha}=\frac{1}{N} \sum_{i=1}^{H}\left(\frac{z-y_{i}}{z}\right)^{\alpha}
$$

Where: $\alpha=$ FGT index which takes value 0,1 and 2 . Low $\alpha$ suggests all the individuals having income below $z$ would be weighted approximately equal by the FGT metric (the higher the $\alpha$, the greater the weight placed on the poorest farmers); $\mathrm{N}=$ Total numbers of sampled farmers; $\mathrm{H}=$ Numbers of farmers below the poverty line. That is those with incomes at or below $z ; Z=$ Poverty line or poverty threshold; $y_{i}=$ Income of each individual farmer $i$.

Poverty Line is 'cut-off' (the minimum) standard of expenditure on food or per capita income. It is defined as:

$$
\text { Poverty Line }(L)=\frac{\text { Total Annual Income of all Farmers }}{\text { Total Number of Farmers }}
$$

Head Count Ratio $\alpha$ equals to zero reduces the formula to the headcount ratio. This is the proportion of individual that lives below the poverty line as compared with the total number of people in the area. The higher the head count value, the greater the proportion of the poor. It is otherwise called the incidence of poverty.

$$
F G T_{0}=\frac{H}{N}
$$

Poverty Gap Index When $\alpha$ equals to one, this gives poverty gap which measures the aggregate short fall of the income/consumption of the poor from the poverty line. The poverty gap indicates the depth of poverty. This is measured as follows:

$$
F G T_{1}=\frac{1}{N} \sum_{i=1}^{H}\left(\frac{z-y_{i}}{z}\right)
$$

The value obtained gives an indication of the amount of money that would make the poor people to cross the threshold of poverty.

The Squared Poverty Gap This measured the 'serenity' or 'intensity' of poverty giving more weight to the poorest. It does this by weighing each poor person by the square of his/her proportionate short fall below the poverty line. In other words, $\alpha$ equals to two suggests the lowest parameter to weigh income inequality along with poverty.

$$
F G T_{2}=\frac{1}{N} \sum_{i=1}^{H}\left(\frac{z-y_{i}}{z}\right)^{2}
$$

\section{RESULTS AND DISCUSSION}

The results show that majority $71.9 \%$ of the respondents were within the ages 19 50years. This indicates that most of the women within this age range are still young and energetic and could take advantage of being energetic to withstand the pressure imposed on them. The results agrees with the findings of Tanko and Jirgi (2008) and Ojo (2013) which all indicated that farmers within this age bracket are more ameable to new ideas and are risk bearing.

In addition Table 1 shows that majority $76.1 \%$ of the respondents are married, $15.0 \%$ are single, while $4.4 \%$ are widowed and divorced. The high percentage of the respondents are married implies that the women will derive benefit of being with their family. It is with agreement with the findings of Tijani et al (2015) who shows that majority of the producers were married thus require extra income to cater for their families food and other basic needs. 
Table 1 below shows that $34.8 \%$ of the respondents have tertiary education, $33.0 \%$ have secondary education, $17 \%$ have primary education, $5.4 \%$ have quaranic education and $9.8 \%$ have no formal education. This implies that majority of the women were literates and this implies that the respondents could employ various strategies to address the issues related to poverty. This agrees with the findings of Akeweta et al (2014) who expressed that the respondents' level of literacy is good enough to help their enterprises.

On the household size the result in table 4 revealed that $86.6 \%$ of the women had a family size of between $1-10$ persons, $10.7 \%$ of the women had had $11-20$ persons, while just a few $3 \%$ of the women had a family size of 21 persons and above. This means there will be availability of labour for increased coping with poverty activities. Osondu et al (2014) who stated that in the presence of constraints to farm labour availability, large households then to use family members as source of labour.

$53.8 \%$ are self employed, private employment, civil servants while $8.8 \%$ are unemployed. $29.3 \%$ have had experience in farming of $1-10$ years, $29.1 \%$ have experience of $11-20$ years, $20.35 \%$ has experience of $21-30 y e a r s, 17.5 \%$ has experience $31-40 y e a r s$ and $3.9 \%$ has experience of 41 and above. This shows as women farmers they have experience in production. Their income from production provides income to deal with poverty. The table below shows that $61.8 \%$ of the women belong to an organization while only $38.2 \%$ of them are not members of any organization.

Table 1 - Socio-Economic characteristics of the respondents in the Study Area

\begin{tabular}{|c|c|c|}
\hline Variable & Frequency & Percentages \\
\hline \multicolumn{3}{|l|}{ Ages } \\
\hline $19-25$ & 7 & 6.3 \\
\hline $26-31$ & 28 & 24.3 \\
\hline $32-40$ & 33 & 28.8 \\
\hline $42-50$ & 26 & 22.5 \\
\hline $51-60$ & 11 & 9.9 \\
\hline 65 and above & 9 & 8.1 \\
\hline \multicolumn{3}{|l|}{ Marital status } \\
\hline Married & 87 & 76.1 \\
\hline Single & 17 & 15.0 \\
\hline Widowed & 5 & 4.4 \\
\hline Divorced & 5 & 4.4 \\
\hline \multicolumn{3}{|l|}{ Education } \\
\hline Tertiary education & 39 & 34.8 \\
\hline Secondary education & 37 & 33.0 \\
\hline Primary education & 19 & 17.0 \\
\hline Quaranic education & 7 & 5.4 \\
\hline \multirow{2}{*}{\multicolumn{3}{|c|}{ Household }} \\
\hline & & \\
\hline $1-10$ & 100 & 86.6 \\
\hline $11-20$ & 11 & 10.7 \\
\hline 21 and above & 3 & 3 \\
\hline \multicolumn{3}{|l|}{ Occupation } \\
\hline Private employment & 9 & 11.3 \\
\hline Self employment & 42 & 53.8 \\
\hline Civil servant & 12 & 15.0 \\
\hline Unemployment & 7 & 8.8 \\
\hline Others & 9 & 11.3 \\
\hline \multicolumn{3}{|l|}{ Farming experience } \\
\hline $1-10$ & 38 & 29.3 \\
\hline $11-20$ & 33 & 29.1 \\
\hline $21-30$ & 21 & 20.3 \\
\hline $31-40$ & 18 & 17.5 \\
\hline 41 and above & 4 & 3.9 \\
\hline \multicolumn{3}{|l|}{ Members } \\
\hline Yes & 70 & 61.8 \\
\hline No & 44 & 38.2 \\
\hline Total & 114 & 100 \\
\hline
\end{tabular}


Poverty status of the respondents. The table represents the FGT index analysis of poverty status among the respondents in the study area. 47 of the women in the study area were found to be poor while 67 were seen to be non poor. The poverty status of the women was analyzed using three indicators such as poverty incidence, poverty gap and severity of poverty. The poverty line is an income-based threshold line that divides the poor and the non-poor farm households in the study area The value of the poverty line is $\$ 260,549$ per annum. Poverty incidence defined as the prevalence of poverty or head count indicates the percentage of the women falling below the poverty line, the poverty gap (poverty depth) shows the amount by which the poor fall short of the poverty line and severity of poverty is the sum of the square of poverty depth divided by the number of sampled respondents. As shown in the table, the poverty incidence among the respondents in the study area was 0.42 representing $42 \%$ of the respondents with income falling below the poverty line, the poverty gap 0.29 representing $29 \%$ whose average income was below the poverty line. This gap represents the percentage of income required to bring poor respondents below the poverty line up to the poverty line. The severity of poverty index was 0.33 which represents the poorest among the poor respondents. The findings agree with Adeolu and Taiwo (2004) on the prevalence of poverty in the rural areas.

Table 2 - Poverty Status of the women in the Study Area

\begin{tabular}{ll}
\hline Poverty Indices & FGT Value \\
\hline Poor & 47 \\
Non-poor & 67 \\
Poverty incidence $\left(P_{0}\right)$ & 0.42 \\
Poverty Gap $\left(P_{1}\right)$ & 0.29 \\
Poverty severity $\left(P_{2}\right)$ & 0.33 \\
Poverty line & \\
$2 / 3$ of income per annum & $N 260,549$ \\
$1 / 3$ of income per annum & $N 86,849$ \\
\hline
\end{tabular}

Table 3 - Percentage distribution of the respondents by their poverty coping strategies

\begin{tabular}{lll}
\hline Items & Yes & No \\
\hline Gift from members of family & $90(78.95)$ & $24(21.05)$ \\
Selling of farm produce & $98(85.96)$ & $16(14.04)$ \\
Praying to God in Church or Mosque & $100(87.72)$ & $14(12.28)$ \\
Involving in town development unions & $87(76.32)$ & $27(23.68)$ \\
Support from Local leaders & $70(61.40)$ & $44(38.60)$ \\
Eating starchy food without meat & $72(63.16)$ & $42(36.84)$ \\
Deny oneself and family of proper & $57(50.0)$ & $57(50.0)$ \\
Selling asset & $58(50.88)$ & $56(49.12)$ \\
Personal savings & $99(86.84)$ & $15(13.16)$ \\
Borrowing from friends and relations & $82(71.93)$ & $32(28.07)$ \\
Packaging of left over food at social function & $53(46.49)$ & $61(53.51)$ \\
Denying oneself and family of food & $43(37.72)$ & $71(62.28)$ \\
Withdrawing of children from school & $51(44.7)$ & $63(55.26)$ \\
Running away from creditors & $56(49.12)$ & $58(50.88)$ \\
Buying food on credit & $53(46.49)$ & $61(53.51)$ \\
Taking credit for benefit & $59(51.75)$ & $55(48.25)$ \\
\hline
\end{tabular}

Source: Field survey, 2019. Figures in brackets are percentages.

Poverty coping strategies of the respondents. There are different poverty coping strategies used by the women in the study area to cope with poverty and they are listed in the table below. $78.95 \%$ of the respondents collect gifts from their family members, $85.96 \%$ sale their farm produce, $87.72 \%$ pray to God in the church or mosque, $76.32 \%$ involve themselves in town development unions. $61.40 \%$ of the women are local leaders, $63.16 \%$ eat starchy food without meat as their coping strategy, $50.0 \%$ deny themselves and their family proper medical care when needed, $50.88 \%$ sale their assets so as to get money to deal with poverty, $86.84 \%$ use their personal savings to cope with poverty, $71.93 \%$ of the respondents borrow from friends and relations, $46.49 \%$ pack left over from social event, $37.72 \%$ deny 
themselves and family food and clothing while $37.7 \%$ withdraw children from school, $49.12 \%$ run from creditors, $46.49 \%$ buy food on credit, $51.75 \%$ take credit for granted. The major poverty coping strategies used by the women in the study are were praying in the church or mosque, Gifts received from better members of the family, selling of farm produce, borrowing from friends and family, involving in town development unions and personal savings.

Table 4 - Effect of poverty among the women in the study area

\begin{tabular}{lll}
\hline Effect & Yes & No \\
\hline Poor and crude storage/ processing equipment & $91(79.82)$ & $23(20.18)$ \\
Lack of access to fund & $95(83.30)$ & $19(16.67)$ \\
Lack of accessible market & $74(64.91)$ & $40(35.09)$ \\
Poor housing condition & $79(69.30)$ & $35(30.70)$ \\
Physical health problem/ disability & $54(47.37)$ & $60(52.63)$ \\
High level of starvation or hunger & $66(57.89)$ & $48(42.11)$ \\
\hline
\end{tabular}

Source: Field survey, 2019. *values in bracket are percentages.

Constraints encountered by the respondents. The table below shows that all the respondents were adversely affected by poverty among the women in the study area. $79.82 \%$ of the women had low standard of poor crude storage processing equipment, $83.3 \%$ had lack of access to funds, $64.91 \%$ had low accessibility to market, $69.30 \%$ had poor housing conditions. Also $47.37 \%$ had physical health problem while $57.89 \%$ were affected by high level of starvation and hunger. The major constraints encountered by the respondents were poor and crude storage/processing equipment this may be so because they cannot afford to use modern technologies, also lack of access to funds because they are small scale farmers and poor housing conditions.

\section{CONCLUSION}

Poverty still exists among the respondents in the study area despite numerous poverty alleviation programs that have been in place. Results of the Foster-Greer and Thorbecke poverty index analysis revealed that $47 \%$ of the respondents were poor with 0.29 and 0.33 as their poverty depth and severity respectively.

Government should promote opportunities for empowering women in Kargako in order to help them overcome the effect, Constraints such as the use of poor or crude storage/processing implements, lack of access to funds and poor housing should be addressed so as to reduce the effect of poverty on the respondents.

\section{REFERENCES}

1. Adeolu, B. and Taiwo, A. (2004). The impact of National Fadama Facility in alleviating rural poverty and enhancing agricultural development in Southern western Nigeria. Department of Agricultural Economics, Obafemi Awolowo University, Ile-Ife, Nigeria.

2. Akeweta, N.J., Ndaghu, A.A and Kefas, P.D.(2014). Livelihood as poverty coping strategy of ruralwomen dwellers of Batagarawa Local Government Area of Kaduna State, Nigeria. Mediterranean Journal of Social Sciences. 6(6):296-306.

3. Foster,J.G, Greer, J and Thorbecke, E.(1984). A class of Decomposable Poverty Measures, Econometrica 52:761:776.

4. Musick, K and Mare, R.D. (2004). Family Structure, Intergenerational Mobility, and the Reproduction of Poverty: Evidence for Increasing Polarization? Journal Storage, 41(4):629-648.https://www.jstor.org/stable/1515223.

5. Moghadam, V. (2005). "The 'Feminization of Poverty' and Women's Human Rights," Papers in Women's Studies and Gender Research, No. 2, July.

6. National population Commission (NPC), (2004). Population and housing census of federal republic of Nigeria, Kogi State. 
7. Ogwumike, F. O. (2012) and appraisal of poverty reduction strategies in Nigeria, www.cenbank.org

8. Ojo, M.A. (2013). Analysis of production efficiency among small scale yam and cassava farmers in Niger and Kogi States, Nigeria. Unpublished Ph.D thesis, Department of Agricultural Economics and Extension Technology, Federal University of Technology Minna, Niger State, Nigeria pp60-75.

9. Osondu, C.K, Ezeh C.I, Emerole, C.O and Anyiro, C.O. (2014). Comparative Analysis of Technical Efficiency of Small Holder Fadama 2 and Fadama 3 Cassava Farmers in Imo State, Nigeria. Nigerian Journal of Rural Extension and Development. 8: 26-37.

10. Tanko, I and Jirgi, A.J. (2008). Agricultural Credit and relative production efficiency in sorghum based cropping enterprises in Kebbi State, Nigeria. Journal of Research in Agriculture, 5(2):39-40.

11. Tijani, B.A, Tijani, H and Tijani A.N. (2015) Resource Use Efficiency in Poultry Egg Production in Maiduguri and Environs of Borno State, Nigeria. Journal of Economics and Sustainable Development 6, 9.

12. World Bank (2007): Pocalnet poverty Data". World Bank. Retrieved 2010-10-24.

13. World Bank (2009) World bank Annual Report 2009.http://doi.org/10.1596/978-0-082137946-2. 